\title{
The role of liquidity risk in augmenting firm value: lessons from savings and credit cooperatives in Kenya
}

Kariuki Florence Waitherero ${ }^{1}$, Stephen Muchina ${ }^{2}$, Stephen Macharia ${ }^{3}$

Department of Business and Economics, Karatina University ${ }^{1,2,3}$

kariukiflorence@gmail.com

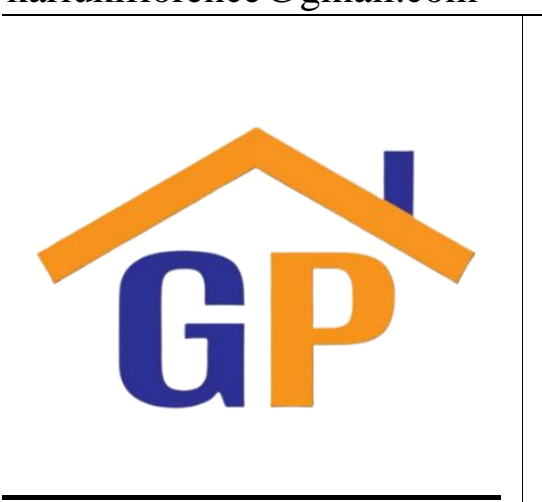

\section{Article History}

Received on 28 October 2020

$1^{\text {st }}$ Revision on 21 December 2020

$2^{\text {nd }}$ Revision on 11 January 2021

Accepted on 14 January 2021

\begin{abstract}
Purpose: The study aimed to examine the interaction between liquidity risk and the firm's value among Kenyan SACCOs.
\end{abstract}

Research methodology: This study adopted the positivism research philosophy and utilised both descriptive and causal research designs. The study targeted all the 164 licenced SACCOs in Kenya. A sample made up of 115 respondents was selected using a stratified random sampling method. The study utilized secondary data obtained from organization's published financial statements. Analysis of data was done using descriptive statistics and inferential analysis.

Results: The study results illustrated that value of the firm was positively correlated with liquidity risk which significantly and favourably impacted the firm value; $(\beta=0.014577, \mathrm{P}=0.001)$.

Limitations: The analysis and conclusions reached in this study were limited to data gathered for the five-year duration between 2012 and 2016.

Contribution: This study is useful to the management of SACCOs and the Kenyan government to understand better how financial risk management can improve their firms' value. The study adds to the existing knowledge of financial risk management and firm value.

Keywords: Savings and credit cooperatives, Liquidity risk, Firm value

How to cite: Waitherero, K. F., Muchina, S., \& Macharia, S. (2021). Role of liquidity risk in augmenting firm value: lessons from savings and credit cooperatives in Kenya. International Journal of Financial, Accounting, and Management, 2(4), 295304.

\section{Introduction}

Fundamentally, SACCOs' existence as part of the financial institutions is crucial for financial deepening and economic development of any economy (Lagat, et al., 2013). This is attributed to their extensive networks both in urban and rural areas. They play a key role in socio-economic development by providing easy access to financial services, encouraging savings, and creating employment opportunities (Mathuva \& Kiweu, 2016). SACCOs are also known to stimulate sprout and growth of business opportunities, living conditions for their members through increased income. They mobilise savings and offer loans to their members at a competitive interest rate. For this reason, SACCOs has been identified as an integral component of the Kenyan government's economic strategy, particularly in eradicating poverty (Sadgrove, 2016). They pride in being one of the leading sources of credit for socioeconomic development to entrepreneurs and SMEs, who may find it difficult to get loans from commercial banks (Kariuki, 2017). 
However, the environment in which SACCOs operates is quite dynamic and characterised by impulsive dynamics when it comes to rates of interest, foreign exchange rates, and other factors that influence their operating incomes (Kinney, et al., 2019). Accordingly, SACCOs operate in highly risky environments. Among the major risks that are inherent include foreign exchange, market, inflationary and political risk (Goede, et al., 2018). Hutson and Stevenson, (2010) noted that a common risk that SACCOs suffer from is financial risk, including foreign exchange, credit, interest rate, liquidity, and capital management risks. In this sense, SACCOs constantly endeavour to control and mitigate the adverse effects of risk exposure. From observation, these firms survival is pegged on their ability to control their financial risks (Elbadry, 2018). According to the provisions of agency theory, the owners of the SACCO who are the contributors of the share capital, engage professional managers to run the business on their behalf with the expectation that they will run the business in their best interest to enhance the value of the firm. However, the managers may prejudice this objective if they do not evaluate investments optimally, leading to losses in capital investment.

According to Bessis (2011), risk management involves setting goals, risks identification, assessment, determining control activities, monitoring, and communication of these risks to reduce exposure to externalities. As pointed out by Sadgrove (2016), when risk management is undertaken with the seriousness it deserves, it is instrumental in achieving organisational goals. Notably, Askari, et al. (2011) opined that a risk management strategy improves financial performance, which influences its value. In agreement with this, McNeil, et al. (2015) notes that the management of financial risks reduces expenditure, more revenue, increased customers, and production of maximum profitability for an organisation. It is essential to point out that firms with effective risk management strategies can sail through financial and economic crises (Goede, et al., 2018).

This study has noted that previous scholarship has given prominence to interest rate risk (Piazzesi, et al., 2010; Drechsler, et al., 2018; Gomez, et al., 2020; Beutler, et al. 2020), credit risk (Saunders \& Allen, 2010; Duffie \& Singleton, 2012; Siddiqi, 2012; Huang \& Huang, 2012; Bonsall, Holzman \& Miller, 2017) as elements of financial risk. This is understandable since these institutions' primary activities are to accept deposits and advance loans that predominantly expose them to credit risk and interest rate risk (Kinney, et al., 2019). However, SACCOs also borrow from commercial banks and the central bank to meet their customer demands. This exposes them to another latent risk of the inability to meet their short-term money obligations when they need to be paid.

Empirical evidence postulates that the firm value is directly related to dividend policy of the firm which outlines how much to pay as dividend, when to pay and how to pay the dividend (Kostyuk, 2006), capital structure, firm profitability (Modigliani and Miller, 1958) firm leverage (Fama \& French, 2002; Chen, Chung, Hsu \& Wu, 2010; Hutson \& Stevenson, 2010). In addition, investment decisions and cash flows generated by the firm influence the organisation value. Firms should invest in investments that generate positive Net Present Value (NPV) increases the organisation value (Modigliani \& Miller, 1958; Minnis 2011). Saunders and Cornett (2014) noted that the levered firm's value must be bigger than the unlevered firm value since the former benefits from the tax shield on the loan interest as a result utilising debt in the capital structure. This suggests that scholars have not adequately researched on the association between the firm value and liquidity risk.

Firm's liquidity as noted by Kamunde (2011) is quantified through its ability to pay its debts obligations in time and the gearing level, which positively affects the firm value. According to Greuning and Bratanovic (2009), financial institutions measure their liquidity adequacy as the ability to access funds easily and at a fair rate. Liquidity according to Akhtar, Ali and Sadaqat (2011) is determined by cash and cash equivalents separated by the gross average reserves. Liquidity ratios equate the existing assets of the firm to the current liabilities. In this study, liquidity risk is measured using current ratio quantified as the current assets ratio to current liabilities. This measure determines if the firm can meet its short-term maturing obligations by utilising its liquid (current) assets. Thus, the measure illustrates the current assets that can be used for every shilling of current liability to be paid (Hutson \& Stevenson, 2010).

2020 | International Journal of Financial, Accounting, and Management/ Vol 2 No 4, 295-304 
Cooperative society is said to be an independent institution made up of members who voluntarily join together to reach common economic, cultural or social goals by use of an enterprise that they jointly own and operate in a democratic manner (WOCCU, 2018). The establishment of the Lumbwa Cooperative Society by European colonists in 1908 in Kenya was the onset of the developments of Saccos (Njenga \& Jagongo, 2019). SACCOs have gradually responded to the dynamic and competitive economic setting. In Kenya, SACCOs controls approximately Ksh 490 billion in assets and savings, equivalent to 55\% of the domestic budget (SASRA 2018). The World Council of Credit Unions explains that Kenya's SACCOs sector is one of the fastest-growing globally. In a 2015 report provided by WOCCU (2015), Kenyan SACCOs were ranked as the fasted growing in Africa while in the world, the sector was ranked $7^{\text {th }}$. Kenya has also been recognised globally due to the growth of its SACCO sector. In 2004, the country was ranked among the top ten most developed global SACCO movements. Other countries who were part of this list included Costa Rica, Canada, Caribbean, Australia, Poland, Mexico, Brazil, USA and Ireland. According to the Kenya Union of Savings \& Credit Co-operative KUSCCO (2018) Kenya based SACCO's offers services to the different cooperatives in the African continent including those in South Africa, Ethiopia, South Sudan and Rwanda.

Savings and Credit Cooperatives are by their nature vulnerable to numerous risks arising from their weak organisational structures, weak regulatory environment and limited access to resources as they rely on member contribution for their capital (Sadgrove, 2016). Moreover, there is little control and monitoring of risks among SACCOs, resulting in increased default among creditors. Additionally, many SACCOs lack governance policies and strategies to ensure that credit risk processes provided are followed. Further, in the international arena, financial risk is accompanied by cultural, legal, and political risks, which exposes these businesses to more risks in their operations and business transactions (Minnis, 2011).

Consequently, most SACCOs in Kenya face huge loan backlogs, which expose them to credit risk resulting from defaulting borrowers. As a result, most SACCOs result in less risky short-term lending, which is less profitable than long-term lending (World Bank, 2016). It was noting that these challenges affect the value of SACCOs. Although many scholars have attempted to interrogate the construct of firm value, they have focused on factors affecting the firm value (Fama \& French 2002). Saunders and Allen (2010), Kostyuk (2006) and Minnis (2011) further pointed out that the firm's value is impacted by different complex factors such as capacity to grow, levels of liquidity, efficiency of operations and the level of leverage. Among SACCOs, determination of firm value has been a complex issue mainly because the construct is multifactor and their shares are not traded openly in the exchange market.

According to Christoffersen (2012), financial risk leads to financial challenges for the firm which affects the company's value negatively. Additionally, there was a favourable association between the firm's value and corporate social responsibility, firm governance, the rate of market capitalization and the dividend policy (Kipruto, 2014; Yuko, 2016). From the literature, an attempt to desegregate financial risks into the various components and seek the effect of each on firm value is not clear. Furthermore, local studies have focused more on public limited companies and none has been conducted on SACCOs. Therefore, this study seeks to examine the relationship between liquidity risk and value of the firm among SACCOs in Kenya.

\section{Literature review}

Liquidity risk results from an organisation's inability to deal with its uncertainties due to changes in the firm cash flows (Drehmann \& Nikolaou, 2013). As noted by Acerbi and Scandolo (2008), when a firm has liquidity problems, it's likely to borrow loans from other financiers that have high-interest rates which result to reduced strong earnings due to the payments of the loan and its high interest. Financial institutions often suffer from lack of funds due to defaulters who cannot pay their loans and the interest. This leaves these institutions in a difficult position as they no longer can raise money to meet the demand for loans from other borrowers. As a result, financial institutions such as SACCOs 
ought to be able to determine their liquidity risk based on the operations available on their balance sheet and other factors that can impact their sources and use of financial resources and also impact the performance and sustainability if these institutions (Lin, Wang \& Wu, 2011). In addition, SACCOs ought to consider the links that are related to liquidity uncertainties plus other kinds of risks such as credit and interest rates risks that can affect the liquidity of the institutions and its sustainability in the financial sector.

An observation made by Basel Committee (2008) was that it's prudent for every firm that wants to succeed to manage its liquidity risk. This is important for even firms in a certain sector or industry as liquidity problems in one organisation in such an industry can affect other organisations as well. Banks that have enough liquidity are able to deal with unforeseen expenses and be able to have enough money for expansion and growth (Greuning \& Bratanovic, 2009). Devinaga (2010) explains that banks are expected to adhere to certain liquidity regulations and limits. Past research has shown that organisations liquidity is favourably correlated to its financial performance (Mwangi, 2014). As explained by Greuning and Bratanovic (2009), liquidity adequacy is determined by banks and other financial institutions as the ability to get money promptly and at an affordable cost. As defined by Akhtar, Ali and Sadaqat (2011), liquidity is determined by dividing the firm's cash and cash equivalents with its average assets. There have been numerous studies in the topic of liquidity and the management of risks by firms.

One such study done by Akhtar, Ali and Sadaqat (2011) compared the management of liquidity risk between Pakistan convectional and Islamic banks. The study sought to determine the influence of the firms' size, the Return on Assets (ROA), Capital adequacy, return on equity, and networking capital on Islamic and convectional banks' liquidity management in Pakistan. The results revealed a favourable and insignificant association between the banks size and networking capital with liquidity risk.

On a regional perspective, Tseganesh (2012) study investigated the influencers of financial institutions liquidity and how these impacted on the banks financial performance. The Ethiopian based study regressed the commercial banks data using a fixed effect panel model. The data from the eight banks was gathered between 200 and 2011. The factors that were illustrated to affect performance were eight. It was illustrated that the size of the bank, amount of non-performing loans, short-term interest rate, rate of inflation, interest rate margin, the loans amounts, and capital adequacy statistically and favourably impacted the institutions liquidity. The factors that unfavourably impacted performance of the banks included short-term interest rate and non-performing loans. Inflation and the interest rate margin were illustrated to have an unfavourable and statistically insignificant influence on performance. The conclusion reached was that bank liquidity impact of banks financial performance was non-linear. However, this study only considered one component of financial risk ignoring the rest.

Another study illustrated the association between liquidity and the profitability of banks listed in Ghana. The study used panel data that was collected between 2005 and 2010 where seven from the listed nine banks data was used. Financial reports were analysed from the seven banks mentioned, and related liquidity and productivity ratios were determined. The use of time series research calculated patterns in liquidity and productivity. According to this study's findings, a weak but favourable association between the study variables was recorded (Lartey, Antwi \& Boadi, 2013). Another study investigated how earnings and dividend policy impacted the prices of shares of sampled Nigerian banks. This study that was conducted by Anike (2014) made use of ex-post-facto research design and gathered panel data from banks annual records in five years between 2006 and 2010. The study's outcome indicated that dividend yield unfavourably impacted the prices of stocks of the sampled banks. Earnings yield was also unfavourable but significantly impacted the share prices and the dividend pay-out ratio of the banks. The study concluded that pay-out ratio, dividend yield and earnings yield did not impact the banks' prices of share but the bank size was concluded to favourably and significantly impact the banks' share prices. 
In the local scene, Omondi and Muturi (2013) looked into the factors influencing firms' financial performance listed in the Kenyan Nairobi Securities Exchange (NSE). The explanatory research focused on 29 NSE listed firms which did not include listed insurance and banking firms that had been part of the NSE between 2006 and 2012. The sample was purposively sampled and used descriptive statistics as well as inferential statistics were used data analysis. The results revealed that company age, size, liquidity, and leverage are a few factors impacting the firm's performance. The study also found a favourable association between the firm's net profit after tax and dividends, revenue and total assets (Kiuru, 2014).

Another research determined the impact of the components of management of working capital on the firm profitability Mathuva (2015). The survey of 30 companies listed on the Nairobi Stock Exchange (NSE) was used for the period 1993 to 2008 to analyse the effect of the management of working capital on the firm's profitability. Both clustered OLS and fixed-effect regression models have been used in data analysis. The findings indicated a favourable and significant association between average period of payment, inventory conversion period, and firm profitability. Another study conducted by Nderi (2016) aimed to determine the association between CSR and the value of listed organisations in the NSE. The results illustrated that firms that engaged in CSR improved their value. This study however only focused on listed firms in Kenya and therefore the findings of this study may not be applicable among SACCOs.

However, majority of the existing studies on liquidity risk sought its linkage with other variables such as financial performance (Akhtar, Ali \& Sadaqat, 2011; Kimondo, 2014; Kiuru, 2014; Mathuva, 2015) other studies just sought to determine the determinants of liquidity (Tseganesh, 2012). This study sought the link between liquidity risk and value of the firm. Most studies reviewed were done in international nations such as Pakistan (Akhtar, Ali \& Sadaqat, 2011), Ethiopia (Tseganesh, 2012), Ghana (Lartey, Antwi \& Boadi, 2013) and Nigeria (Anike, 2014) implying that these results may not perfectly match the current context. Moreover, most of the studies reviewed were conducted in the banking sector, listed companies and insurance companies, which are significantly different from private equity firms in terms of valuation hence the need for the current study.

\section{Research methodology}

The researcher chose to use the positivism research paradigm which consists of the use of theory before the actual research and the use of a testable hypothesis (Cooper \& Schindler, 2011). This research paradigm looks at a social science as a natural research and the hypothesis in this case is tested empirically to determine the truth. The research quality is maintained by ensuring the data used is valid and reliable (Koul, 2008). This research paradigm as noted by Saunders (2011) focuses on neutrality, raw facts, validity of results, objectivity and measures the results. The paradigm also looks at knowledge using the facts available without bias or abstractions. The knowledge is obtained through experiments and observations unlike the searching of the meaning of phenomenon as sought in the phenomenological paradigm (Neuman \& Robson, 2014).

The study also made use of casual and descriptive research designs. The latter research design was necessary to help describe the SACCO traits and the variables under investigation and describe, "What exists" concerning variables and conditions in a situation as recommended by Ojukwu (2013). On the other hand, causal research design or explanatory research design, determines the nature and extent of the cause-and-effect association between study variables. As noted by Sekaran and Bougie (2016) explanatory research design seeks to give the impact of the changes of existing processes and focuses on the analysis of a given issue to explain the association between variables under research. The causal design was also employed to determine the cause and effect of the relationship between the liquidity risk and the firm's value among Kenyan SACCOs.

The study utilised secondary data gathered from the respective SACCOs financial records. Crosssectional panel data from all selected SACCOs for each year over the seven years starting from 2010 to 2016 was collected. The study targeted the total 164 licenced Kenyan SACCOs. The population 
was classified into five clusters based on the original bond and criteria for membership at incorporation as shown in SACCO supervision annual report of 2017. A stratified random method of sampling helped choose the sample size of 115 deposit taking SACCOs). To analyse the data obtained, the study used both descriptive statistics and inferential analysis in data analysis. Descriptive statistics such as kurtosis, skewedness, standard deviation and average helped characterise the results in terms of central tendency and dispersion. Inferential statistics using Pearson correlation coefficient and a regression model helped analyse panel data to capture the interaction liquidity risk on value of the SACCOs.

The coefficient of determination $\mathrm{R}^{2}$ was used to determine the model's fit and determine the variation in the firm's value as indicated by changes in liquidity risk. F-statistic was determined at a $5 \%$ level of significance to determine if there was a significant association between liquidity and the firm value of SACCOs in Kenya. Moreover, the student's $(t)$ test and the $p$-value helped in hypothesis testing. The adjusted $\mathrm{r}^{2}$ and F-statistic helped determine the model fitness while the value of $\mathrm{p}$ was provided from the significance and alpha levels.

\section{Results and discussions}

The outcomes from descriptive statistics on the study variables are as indicated in the below Table 1 .

Table 1. Financial Risk Profile of SACCOs

\begin{tabular}{lccccccc}
\hline Variable & Obs & Mean & Std. Dev. & Min & Max & Skewness & Kurtosis \\
\hline Liquidity Risk & 410 & 143.1899 & 397.5731 & .003955 & 3254.14 & 0.392 & 3.425 \\
Value of the Firm & 410 & 1.517546 & 3.517641 & -11.6478 & 33.85699 & 0.768 & 3.1059 \\
\hline
\end{tabular}

Source; Research data (2019)

Table 1. illustrates that liquidity risk had an average of 143.1899 shillings and a standard deviation of 397.5731 shillings. It was also noted that the minimum observation for the variable was 0.0039554 while the maximum value was 3254.14. Based on these observations, the average current ratio, shown as the ratio of current assets to current liabilities, was way above the recommended current ratio 2 . Thus, it is deduced that most of the SACCOs had numerous current assets to pay short-term maturing current liabilities. However, the results also show a wide range of the current ratio implying that some SACCOs had very low ratio while others had a high current ratio. The study concluded that most SACCOs were liquid and sound which shows the relevance of liquidity risk management to these SACCOs. These results were similar to the observations made by Mwangi (2014) who concluded that firm liquidity is positively correlated with its financial performance, which in turn affect the firm value. The outcomes were not in agreement with the observations of Lartey, Antwi and Boadi (2013) that liquidity association with profitability and firm value was weak but favourable.

The average value for the firm's value was recorded as 1.517546 billion while the standard deviation was observed to be 3.517641 billion. From these observations we can say that there was a great change in the Kenyan SACCOs values as some of the outcomes showed positive findings while others showed unfavourable findings. This can be seen from the recorded values as some were as low as 11.64775 billion while others went as high as 33.85699 billion. These great disparities can be caused by the factors affecting the SACCOs' value such as liquidity, capital management, credit, and interest rate risks. The capital expenditure from the observed institutions was quantified by considering the fixed assets investments. But according to the SACCO 2010 requirements, they must keeo15\% of their savings in liquid form. Capital expenditure formed an essential part of the firm value but unfortunately some of the SACCOs had negative firm value as they lacked capital expenditure. The firm value was quantified using non-cash working capital and earnings before interest and taxes (EBIT) and both were shown to impact the firm value in a significant way. Additionally, liquidity risk had a Kurtosis value greater than three. According to Kallner (2014), a standard normal distribution has a kurtosis of 3 and is described as mesokurtic. Consequently, the firm's liquidity risk and value 
were described as being leptokurtic, suggesting that most Saccos had few current ratios and Free Cash Flow to Equity.

The study also conducted panel data regression to determine the relationships between liquidity risk and Kenyan SACCOs' value. In this case, the firm value was regressed on liquidity risk. The study also tested the null hypothesis that liquidity risk did not significantly impact the firm value among SACCOs in Kenya. Further, the firm value was regressed on liquidity risk and the findings were as seen in Table 1.2.

Table 1. Association between Liquidity Risk and Value of the Firm

\begin{tabular}{|c|c|c|c|c|c|c|}
\hline Source & SS & Df & \multicolumn{2}{|c|}{ MS } & Number of obs & $=410$ \\
\hline & & & \multirow{2}{*}{\multicolumn{2}{|c|}{3831.4783}} & $F(1,408)$ & $=322.469$ \\
\hline Model & 3831.47834 & 1 & & & Prob > F & $=0.0000$ \\
\hline \multirow[t]{2}{*}{ Residual } & 4847.73595 & 408 & \multicolumn{2}{|c|}{11.8817} & R-squared & $=0.7571$ \\
\hline & & & & & Adj R-squared & $=0.7565$ \\
\hline Total & 5060.88378 & 409 & \multicolumn{2}{|c|}{12.373799} & Root MSE & $=3.447$ \\
\hline $\begin{array}{l}\text { Value of the } \\
\text { firm }\end{array}$ & Coef. & Std. Err. & $\mathbf{T}$ & $P>t$ & [95\% Conf. & Interval] \\
\hline Liquidity risk & 0.18158 & .004287 & 42.46 & 0.000 & .00973 & .026585 \\
\hline _cons & 1.257545 & .1809643 & 6.95 & 0.000 & .9018066 & 1.613284 \\
\hline
\end{tabular}

Source; Research data (2019)

According to the findings, liquidity risk coefficient value was 0.18158 indicating that when other factors were constant, a rise in a unit of current ratio resulted to a 0.18158 rise in the SACCO value. At the same time, the study found that the constant coefficient was at 1.257545 meaning that if the current ratio was constant, the SACCO value would be at 1.257545 . Liquidity risk coefficient $t-$ statistic value was illustrated to be 42.46 . T-statistic was higher than the t-critical 1.6486 value. The recorded findings found that the coefficient of liquidity risk value of $\mathrm{p}$ was 0.000 , which was less than 0.05 which was the significance value. From this the null hypothesis was rejected and a conclusion reached that liquidity risk significantly impacted the value of Kenyan SACCOs.

The hypothesis test's impact as seen in Table 2 Indicate that the adjusted R2 value was at 0.7565 proof that the model could explain $75.65 \%$ of the firm value changes. the F-statistic value at $(1,408)$ degrees of freedom was 322.469 which was higher than 3.8644 the F-critical value. The model's value of $\mathrm{p}$ was observed to be 0.000 , lower compared to 0.05 , the significance value. Therefore, the study concluded that the used model could explain the firm's value using both F-statistic and P-value.

The results of the study were also consistent with the outcome of a study by Mwangi (2014) which concluded that firm liquidity is positively correlated with its financial performance and value. These outcomes were also in agreement with Lartey, Antwi and Boadi (2013) study that the association between liquidity and profitability of NSE listed banks was favourable but extremely weak. Moreover, a weak but favourable association between liquidity risk and performance as recorded by (Lartey, Antwi \& Boadi, 2013) were in line with study results. Furthermore, Mathuva (2015) in his study established a favourable and significant association between average period of payment, inventory conversion period, and firm profitability which is consistent with the findings of the study.

However, the results contradicted the results from Akhtar, Ali and Sadaqat (2011) study who found the association between liquidity risk and Networking capital to net assets. Similarly, the findings reached by Tseganesh (2012) that bank liquidity link with financial performance was non-linear was in contradiction to the study results. 


\section{Conclusions}

There is a favourable and significant association between liquidity risk and value of Kenyan SACCOs from the results. The conclusion made was that liquidity risk significantly influences the firm value among SACCOs in Kenya. It was concluded that a unit change in current ratio leads to a positive change in the Kenyan SACCOs value. These findings are additive to the body of knowledge both theoretically and empirically. The conclusions reached were explained on the basis of the postulates of the agency theory, which states that when the agency challenges exists, the shareholders have to deal with agency costs, which results in a reduction in the money that can be used in the firm operations firm to liquidity problems. Empirically, the study helps in bridging the gap in literature by showing the association existing between liquidity risk and Kenyan SACCOs value. Moreover, from the outcomes of the study, it's recommended that the management should seek to improve their liquidity by increasing the proportion of liquid assets such as accounts receivable, cash and cash equivalents. In addition, the management should avoid over reliance on short term liabilities such as short-term loans whose repayment may expose the firm to liquidity problems.

\section{Limitation and study forward}

This study was limited to the SACCOs registered and regulated by SASRA which are significantly controlled by the government. Therefore, the results may not be applicable to non-deposit taking SACCOs. A suggestion is made that a future research be done among the non-deposit taking SACCOs to determine if the same results would be recorded. It's also the recommendation of the study that future studies be done on other financial organisations other than SACCOs such as SMEs to see if the same outcomes would be observed. Since the study established that there is a requirement of SACCOs having $15 \%$ of savings deposits to be in liquid assets it recommended that another study can be done on the influence of this requirement on the value of SACCOs.

The study was limited liquidity risk as determinants of firm value, which is a function of financial risk. The study therefore recommends that another wider study should be conducted to cover other types of risks to establish their effect on the value of SACCOs in Kenya. Finally, since this study was based on SACCOs, which are private capital firms, the study finds that the level of regulation is lower than that of other public equity firms. For this reason, the level of compliance with international accounting and reporting standards is still low among SACCOs as compared to other financial sector firms such as public limited companies and commercial banks. Such firms have different regulating bodies such as NSE and Capital Market Authority. Other studies ought to be conducted in such firms that have multiple level of regulation to establish whether similar results would be established.

\section{Acknowledgement}

We wish to appreciate the management of SACCOs that participated in the study for allowing us to collect the requisite data. More appreciations to National commission for Science and technology for giving us the green light to collect the data.

\section{References}

Acerbi, C., \& Scandolo, G. (2008). Liquidity risk theory and coherent measures of risk. Quantitative Finance, 8(7), 681-692.

Akhtar, M. F., Ali, K., \& Sadaqat, S. (2011). Liquidity risk management: a comparative study between conventional and Islamic banks of Pakistan. Interdisciplinary Journal of Research in Business, 1(1), 35-44.

Anike, E. A. (2014). The impact of dividend policy and earnings on stock prices of Nigeria Banks. Department of Banking and Finance Faculty of Business Administration University of Nigeria, Nsukka.

Askari, H., Iqbal, Z., \& Mirakhor, A. (2011). New Issues in Islamic Finance and Economics: Progress and Challenges (Vol. 753). New Jersey, United States, John Wiley \& Sons.

Basel committee (2008). Annual Report, Basel.

Bessis, J. (2011). Risk management in banking. New Jersey, United States, John Wiley \& Sons. 
Beutler, T., Bichsel, R., Bruhin, A., \& Danton, J. (2020). The impact of interest rate risk on bank lending. Journal of Banking \& Finance, 105797.

Bonsall IV, S. B., Holzman, E. R., \& Miller, B. P. (2017). Managerial ability and credit risk assessment. Management Science, 63(5), 1425-1449.

Chen, W. P., Chung, H., Hsu, T. L., \& Wu, S. (2010). External financing needs, corporate governance, and firm value. Corporate Governance: An International Review, 18(3), 234-249.

Christoffersen, P. F. (2012). Elements of financial risk management. Massachusetts: Academic Press.

Cooper, D. R., \& Schindler, P. S. (2011). Qualitative research. Business research methods, 160-182.

Devinaga, R. (2010). Review of Literature and Theories on Commercial Bank Profitability. Journal of Performance management.

Drechsler, I., Savov, A., \& Schnabl, P. (2018). Banking on deposits: Maturity transformation without interest rate risk (No. w24582). National Bureau of Economic Research.

Drehmann, M., \& Nikolaou, K. (2013). Funding liquidity risk: definition and measurement. Journal of Banking \& Finance, 37(7), 2173-2182.

Duffie, D., \& Singleton, K. J. (2012). Credit risk: pricing, measurement, and management. Princeton university press.

Elbadry, A. (2018). Bank's financial stability and risk management. Journal of Islamic Accounting and Business Research.

Fama, E. F., \& French, K. R. (2002). Testing trade-off and pecking order predictions about dividends and debt. The review of financial studies, 15(1), 1-33.

Goede, H., Christopher-de Vries, Y., Kuijpers, E., \& Fransman, W. (2018). A review of workplace risk management measures for nanomaterials to mitigate inhalation and dermal exposure. Annals of Work Exposures and Health, 62(8), 907-922.

Gomez, M., Landier, A., Sraer, D., \& Thesmar, D. (2020). Banks' exposure to interest rate risk and the transmission of monetary policy. Journal of Monetary Economics.

Greuning, H., \& Bratanovic, S. (2009). Analyzing banking risk: a framework for assessing corporate governance and risk management. New York: World Bank Publications.

Huang, J. Z., \& Huang, M. (2012). How much of the corporate-treasury yield spread is due to credit risk. The Review of Asset Pricing Studies, 2(2), 153-202.

Hutson, E., \& Stevenson, S. (2010). Openness, hedging incentives and foreign exchange exposure: A firm-level multi-country study. Journal of International Business Studies, 41(1), 105-122.

Kallner, A. (2014). Laboratory statistics, handbook of formulas and terms. Chemistry International, 36(4), 23-23.

Kamunde, J. N. (2011). The determinants of firm value in the telecommunication sector in Kenya (Doctoral dissertation). University of Nairobi, Kenya.

Kariuki, N. W. (2017). Effect of credit risk management practices on financial performance of deposit taking savings and credit cooperatives in Kenya. IOSR Journal of Business and Management, 19(04), 63-69.

Kimondo, C. N. (2014). The relationship between liquidity and profitability of nonfinancial companies listed in Nairobi securities exchange (Unpublished doctoral dissertation), University of Nairobi.

Kinney, A. R., Schmid, A. A., Henry, K. L., Coatsworth, J. D., \& Eakman, A. M. (2019). Protective factors that mitigate the indirect risk of combat exposure upon meaning in life: A longitudinal study of student veterans. Psychological Trauma: Theory, Research, Practice, and Policy.

Kipruto, J. (2014). The effect of corporate venture capital on the value of firms listed at the Nairobi Securities exchange. (Doctoral dissertation), University of Nairobi, Kenya.

Kiuru, C. N. (2014). The relationship between dividends and firm's performance: a case study of listed firms in the Nairobi Securities Exchange. (Unpublished project). United States International University, Kenya

Kostyuk, D. (2006). Dividend payout and its impact on firm value, Economics Education and Research Consortium, 6(5), 115-125.

Koul, R. (2008). Education research and ensuring quality standards. E-Journal of All India Association for Education Research, 20(3), 1-8. 
Lagat, F. K., Mugo, R., \& Otuya, R. (2013). Effect of credit risk management practices on lending portfolio among savings and credit cooperatives in Kenya. (Unpublished thesis), University of Nairobi.

Lartey, V. C., Antwi, S., \&Boadi, E. K. (2013). The relationship between liquidity and profitability of listed banks in Ghana. International Journal of Business and Social Science, 4(3), 306-319.

Lartey, V. C., Antwi, S., \&Boadi, E. K. (2013). The relationship between liquidity and profitability of listed banks in Ghana. International Journal of Business and Social Science, 4(3), 812-826.

Lin, H., Wang, J., \& Wu, C. (2011). Liquidity risk and expected corporate bond returns. Journal of Financial Economics, 99(3), 628-650.

Mathuva, D. M., \& Kiweu, J. M. (2016). Cooperative social and environmental disclosure and financial performance of savings and credit cooperatives in Kenya. Advances in accounting, 35, 197-206.

McNeil, A. J., Frey, R., \& Embrechts, P. (2015). Quantitative risk management: Concepts, techniques and tools. New Jersey: Princeton university press.

Minnis, M. (2011). The value of financial statement verification in debt financing: Evidence from private US firms. Journal of Accounting Research, 49(2), 457-506.

Modigliani, F., \& Miller, M. H. (1958). The cost of capital, corporation finance and the theory of investment. The American economic review, 19(12), 261-297.

Mwangi, Y. K. (2014). The effect of risk management on financial performance of commercial banks in Kenya. (Unpublished doctoral dissertation), University of Nairobi.

Nderi, S. (2016). The relationship between corporate social responsibility and firm value of firms listed at the Nairobi securities exchange. (Doctoral dissertation), Kenyatta University, Kenya.

Neuman, W. L., \& Robson, K. (2014). Basics of social research. Saskatoon: Pearson Canada.

Njenga, R., \& Jagongo, A. (2019). Board characteristics, firm size and financial leverage of manufacturing firms listed at Nairobi Security Exchange, Kenya: Theoretical review. International Academic Journal of Economics and Finance, 3(3), 418-426.

Ojukwu, M. O. (2013). Impact of educational attainment on marital stability among married persons in Imo State, Nigeria. International Journal of Education \& Literacy Studies, 4(3) 516-522.

Omondi, M. M., \& Muturi, W. (2013). Factors affecting the financial performance of listed companies at the Nairobi Securities Exchange in Kenya. (Doctoral dissertation), Kenyatta University, Kenya.

Piazzesi, M., \& Schneider, M. (2010). Interest rate risk in credit markets. American Economic Review, 100(2), 579-84.

Sadgrove, K. (2016). The complete guide to business risk management. Abingdon: Routledge.

SASRA. (2018). Sacco supervision annual report 2017: SASRA

Saunders, A., \& Allen, L. (2010). Credit risk management in and out of the financial crisis: new approaches to value at risk and other paradigms (Vol. 528). John Wiley \& Sons.

Sekaran, U., \& Bougie, R. (2016). Research methods for business: A skill building approach. New Jersey: John Wiley \& Sons.

Siddiqi, N. (2012). Credit risk scorecards: developing and implementing intelligent credit scoring (Vol. 3). John Wiley \& Sons.

Tseganesh, T. (2012). Determinants of banks liquidity and their impact on financial performance: empirical study on commercial banks in Ethiopia. (Doctoral dissertation), Addis Ababa University, Ethiopia.

WOCCU (2015). Statistical report 2014. https://www.woccu.org/our_network/statreport

WOCCU (2018). Statistical report 2018. Retrieved from https://www.woccu.org/our_network/statreport

World Bank (2016). World development report (2016). World Bank Documents \& Reports.

Yuko, S. O. (2016). The effect of dividend policy on the value of firms listed at the Nairobi Securities Exchange. (Unpublished doctoral dissertation), University of Nairobi. 